passed. Replies, stating the nearest technical college which could be attended, should be sent to Mr. Puckle as early as possible.

\section{World Power Conference on Fuel Economy}

A PRELIMINARY programme has been issued of a sectional meeting of the World Power Conference to be held at The Hague during September 2-9, 1947, when the subject of discussion will be "Fuel Economy". The proceedings will be divided into three sections dealing with production, distribution and utilization respectively. Copies of national reports on fuel economy prepared at the request of the central office of the World Power Conference and also of all printed papers prepared for the meeting will be supplied to members of the Conference ; all sessions will be devoted to oral discussion. Papers can only be submitted through national committees ; the address of the British National Committee is 201-2 Grand Buildings, Trafalgar Square, London, W.C.2, to which intending members resident in Great Britain should apply for particulars. The address of the secretariat for the meeting is Vereeniging voor Congressen op Electrotechnisch en Aanverwant Gebied, 210 Utrechtscheweg, Arnhem, Netherlands.

\section{X-Ray Analysis Conference}

The 1947 Conference of the X-Ray Analysis Group of the Institute of Physics will be held at the Royal Institution, Albemarle Street, London, during April 22-23. The first day will be devoted to discussion of the training of X-ray erystallographers for science and for industry; the second will be devoted to new techniques and results. Mr. H. P. Rooksby, of the Research Laboratories, General Electric Co. Ltd., Wembley, will give an evening lecture on the technique of X-ray powder photography on April 22. Short papers only are being given, so as to leave time for informal discussions. The Conference is open to all interested in the subject. Further particulars can be obtained from the honorary secretary of the Group, Dr. F. A. Bannister, British Museum (Natural History), London, S.W.7.

\section{Conference on Applications of Radioactive Tracer Elements}

A CONFERENCE is being arranged by the Manchester and District Branch of the Institute of Physics on "Applications of Radioactive Tracer Elements in Physics Research and Industry" during July 10-12 in the Physics Department of the University of Manchester. The opening papers will be given by Dr. J. D. Cockcroft, Prof. F. Paneth and Mr. D. H. Wilkinson. The conference will be open to anyone interested, without charge, but admission will be by ticket only. Further particulars will be issued in due course by the Conference Secretary, W. J. Meredith, Christie Hospital and Holt Radium Institute, Wilmslow Road, Manchester 20.

\section{University of Durham : Appointments}

THe following appointments have been made in the University of Durham: Martin Jones, to be professor of agrieultural botany at King's College, Newcastle; Ewen $M^{\prime}$ 'Ewen, to be professor of engineering in the Faculty of Agriculture at King's College, Newcastle; Alexander Kennedy, to be professor of psychological medicine at King's College, Newcastle; Leonard Slater, to be reader in geography in the Durham Colleges.

\section{Arthur Stanley Eddington Memorial Lectureship}

LAST year an appeal was launched to provide for the founding of an Arthur Stanley Eddington Memorial Lectureship to commemorate Eddington's life and work, by providing for lectures on some aspect of contemporary scientific thought considered in its bearing on the philosophy of religion, or on ethics, and to be delivered periodically in Cambridge, or elsewhere, and to be published. The Foundation Trust Deed has now been completed, and the following four trustees have been appointed: Prof. Sydney Chapman, representing the Royal Society; Prof. C. D. Broad, representing Trinity College, Cambridge; Dr. Kathleen Lonsdale and Dr. W. H. Thorpe, representing the Society of Friends. Mr. Howard Diamond, 45 St. Barnabas Road, Cambridge, is honorary treasurer and secretary of the trustees. The Fund is still open, and approximately $£ 1,000$ is now needed for its completion. It is hoped that the first lecture on the Foundation will take place towards the end of the present year.

\section{The Boron-Trifluoride Catalysed Reaction of Di- isobutene}

Dr. Alwyn G. Evans and M. A. Weinberger write : "In our recent communication on this subject [Nature, March 29, p. 437], it is stated that the addition of acetone vapour, purified by distillation in vacuo over freshly distilled sodium, to a non-reacting mixture of di-isobutene vapour and boron trifluoride initiates the fast reaction of di-isobutene. In our corrected proof of this letter [received too late for changes to be made. Editors] we deleted this statement on the grounds that since traces of water are so effective in initiating this reaction, we do not as yet wish to claim that completely pure acetone itself is effective in this way."

\section{Announcements}

THE James Watt International Medal for 1947 of the Institution of Mechanical Engineers will be presented to Prof. S. Timoshenko, recently professor of engineering at Stanford University, California, on April 25; he will speak on "Stress Concentration and Fatigue Failures".

Mr. F. Brundrett, of the Royal Naval Scientific Service, has been appointed chief of the Service in succession to Sir Charles Wright, who retires on April 30.

By arrangement between the University of Sheffield and the Council of the Iron and Steel Institute, the second Hatfield Memorial Lecture will be given by Dr. C. Sykes, of the Brown-Firth Research Laboratories, Sheffield, in the Institution of Civil Engineers, London, on May 14 at 8.30 p.m., on the occasion of the annual general meeting of the Iron and Steel Institute, and will be entitled "Steels for Use at Elevated Temperatures".

Dr. Douglas Guthrie is delivering a course of lectures in the University of Edinburgh on the history of medicine, beginning on April 17. As part of the course, guest lectures will be given by Sir Arthur MacNalty on the evolution of preventive medicine in Britain on May 16, and by Sir Henry Bashford on Hans Sloane on May 23.

ERratum. In the communication "Spiral Cracks in Glass Tubes" by Dr. L. Norzi, published in Nature of March 1, p. 306, paragraph 5, line 2, for "tg $2 \varphi=2 C|(B-A)| "$ read "tg $2 \varphi=2 C /|(B-A)| "$. 